\title{
The Effect of Autonomy, Personality, Stress and Job Satisfaction to Job Performance of Teachers at Senior High School in Bekasi
}

\author{
Marganda Sitohang ${ }^{1} \quad$ Nurhattati Fuad ${ }^{2} \quad$ Thamrin Abdullah $^{2}$ \\ 1.School of Management, University State of Jakarta, Indonesia \\ 2.Lecture School of Management, University State of Jakarta, Indonesia
}

\begin{abstract}
The objective of this research was to determine the effect of autonomy, personality, stress and job satisfaction to job performance of teachers at Senior High School in Bekasi. The research was conducted using a survey method with path analysis applied in testing the hypothesis. The target population size of this research is 191 of teachers. Research samples selected as much as 364 teachers using simple random sampling technique. Based on this research of data, obtained the following conclusions: (1) the autonomy implies direct positive effect to job performance, (2) the personality implies direct positive effect to job performance, (3) personality implies direct positive effect to job performance, (4) the autonomy implies direct positive effect to job satisfaction, (5) personality implies direct positive effect to job satisfaction, (6) the stress implies direct negative effect to job satisfaction. The conclusion is that the teacher's job performance is affected by the autonomy, personality, stress, and teachers' job satisfaction.
\end{abstract}

Keywords: Job performance, Autonomy, Personality, Stress and Job Satisfaction

DOI: $10.7176 / \mathrm{JEP} / 10-36-15$

Publication date: December $31^{\text {st }} 2019$

\section{Introduction}

An educator wants his or her students to change in a better direction, in terms of attitude, knowledge, and skills. For it is in need of a teacher who is able to bring learners become successful people for the future of their students. The success of a teacher shows that the teacher has done a good job and the learner also gained the knowledge that has been taught. Implementing the task well illustrates that the teacher has done a good performance. A teacher is required to have a high performance in the school environment, where they are on duty. Less optimum performance of teachers will have an impact on the quality of education as it is without accompanied by high teacher's performance, education reform efforts will not reach its optimum results.

Teacher's performance whether it is good or bad, is achieved from the work that has been done by the teacher. Each school leader expects teachers to be able to execute their learning plans so that the implementation of learning in the school can run well, resulting in good work results as well. In reality, the performance of the teachers is still a problem that should get more attention. Teaching as a teacher is very important in advancing education, so that it is considered a necessity to put more efforts in improving teachers' performance.

Performance will rise if teachers see the clarity of career development in their career as a teacher. Improving teachers' performances can be done by giving teachers the opportunity to attend trainings, educational seminars, even with career development. Regulation of the Minister of National Education Number 16 Year 2007 regarding Academic Qualification and Teacher Competency Standards, states that the competence and mastery of materials determine the results of the quality of the process of learning activities. Improving the quality of a person's performance or organization is done for the achievement of performance targets and goals that have been specified. High performance will produce good results, and, through low performance produces results which are not optimum.

Work target in accordance with the planned will create a chance to get a good work as well. Assertive attitude and commitment in performing the task is a capability that must be owned by a teacher. Performance is something that a teacher must master. Understanding of the process of organizing education in school will facilitate the teacher to carry out their duties and functions. The teacher must also find the efforts and strategies in carrying out their duties to achieve the goal of education well. Less optimum of teachers' performance will have an impact on the quality of education, as the education reform efforts will produce optimum results when it is accompanied by high teacher performance.

Yet, in reality the teachers' performances in Indonesia still takes a serious concern. It can be seen from the research data center and statistics of education and culture. The performance of human resources based on 5 education indicator shows that the performance of Primary secondary education is categorized less with value 77,69 , but the performance of principal of Primary secondary education includes middle category equal to 85,43 , and the performance of teacher of Primary secondary education is less than 76,43. Teacher's performance includes on how planning the workings of teachers, the teacher's procedures in carrying out the work and the results of the work. Based on the research above, it shows the performance of teachers in Primary secondary education is still lacking. 
The quality of education will not make any improvements if the performance of teachers is still lacking. This is a problem that should be given attention to all circles, both government and the general public. The Government of Indonesia has made efforts to improve the quality of education, among others through the development and improvement of curriculum, evaluation system, educational infrastructure and facilities, teaching materials, teacher's quality, and other education personnel.

Teacher's performance can also be measured from the achievements of national examinations conducted by the government. The results of the national exam of Senior High School in Natural Sciences Program demonstrate the category $\mathrm{C}$ for national, West Java Province and Bekasi District. National exam results of Senior High School in Social Sciences Program mark that the national, the provincial level (West Java), as well as for district level (Bekasi District), it is in category C. From the results of the national examination, it can be concluded that the teachers' performances still need to be improved, especially in Bekasi. The education policy in Indonesia based on the Law of the Republic of Indonesia Number 20, 2003, on the National Education System, is aimed at achieving eight objectives. One of the objectives of the National Education System is to reform the education system including curriculum renewal, in the form of curriculum diversification to serve the diversity of learners, the preparation of curriculum applicable for national and local in accordance with local interests, as well as the diversification of the type of education in a professional manner. In 2013, Indonesia implemented the 2013 curriculum for the first time. There are 6,221 schools spread over 295 districts and cities throughout Indonesia which have implemented it. The total number of schools consists of 2,598 elementary schools, 1,437 junior high schools, 1,165 high schools, and 1,021 vocational high schools. There are 13 State Senior High Schools in Bekasi District implementing the 2013 curriculum as appointed by the Ministry of Education and Culture. Through curriculum changes, it is expected to improve the quality of education in general, and teacher's performance will be higher specifically.

Looking at the results of Teacher Competency Test in 2015, Bekasi District showed a low result with an average of 57.86. This is still below the provincial level of Teacher Competency Test average (58.97), yet it still above the national average of Teacher Competency Test (56.69). Bekasi District is only ranked 18th out of 27 regencies and cities in West Java district. This of course affects the work of teachers during the duty. The teacher's understanding of his / her educational qualifications is crucial to the mastery of the learning materials and methods in the school. Improving the performance of teachers is very important and that must also be considered more seriously. There are still many low-performing teachers, although they have already had certificates as educators. In the 2013 curriculum pilot project, which involved 13 public schools in Bekasi District, there are 296 certified teachers. That is, of the total number of teachers there are 364 teachers, and then there are $81 \%$ of teachers who have been certified as educators. The number of $81 \%$ is not a small number, and is expected to spur the improvement of education quality in Bekasi District.

Along with the above study, researchers consider the performance of a teacher is an important thing to be studied. This is very reasonable because by knowing the work performance of teachers, we are also able to measure up to which extent teacher has achieved their work target, whether it is good or still need some improvements. Thus, the performance of high school teachers is a determinant factor in the achievement of the quality of education which enables the school to its function and eventually that will affect the success of achieving school goals.

This study looks at any variables which cause the low performance of high school teachers in Bekasi District. Variables that may be related to performance problems are the quality of work life, work autonomy, personality, job stress, job satisfaction, trust, organizational justice, supervision, work motivation and autonomy, and several other factors allegedly affect performance. Researchers will choose 4 variables that can affect performance for high school teachers in Bekasi District. They are work autonomy, personality, stress and job satisfaction. Through literature review, researchers collect a variety of concepts for all variables that will be examined from various sources put forward by a number of experts as reference materials.

\section{Job Performance}

Teacher's performance can be measured with the work and behavior of teachers in carrying out their tasks or work within a certain time with the standards and criteria, to achieve the goals set by the school. A devout teacher doing the work will produce good work. Achievement of work targets and achievement of work standards that have been set will lead to improved performance. Teachers who have the work earned within the stipulated time will have an impact on the school's goals. Achieving school goals will also occur if teachers directly contribute to the school. Thus, performance is the result of work and behavior of an employee in performing tasks or work within a certain time with standards and criteria, to achieve the goals set by the organization. Job performance is the performance of an employee in carrying out his duties or work within a certain period of time with standards and criteria, to achieve the goals set by the organization with indicators: obeying work, achievement of work targets, achievement of work standards that have been set, work results obtained within the stipulated time, and contributions to the goals of the organization. 
Performance is an evaluation of the result of a person's behavior. It involves determining how well or poorly a person has accomplished a task or done a job, Jennifer and jones (2012:158). Performance is formally defined as the value of the set of employee behaviors that contribute, either positively or negatively, to organizational goal accomplishment. This definition of job performance includes behaviors that are within the control of employees, but it places a boundary on which behaviors are (and are not) relevant to job performance, Colquitt, LePine, Wesson (2011:35). Performance is the outcomes of jobs that relate to the porposes of the organization such as quality, efficiency, and other criteria of effectiveness, Gibson et al, (2006:372). Performance is often defined simply in output terms-the achievement of quantified objectives. But performance is a matter not only of what people achieve it. The oxford English Dictionary confirms this by including the prhase 'çarring out' in its definition of performance: the accomplishment, execution, carrying out, working out of anything ordered or undertaken, Armstrong (2006:7). Performance defined as the result of pattern of actions carried out to satisfy an objective according to some standard, Rothwell and Kazanas (2003:402). Performance is the product of ability multiplied by motivation. Performance has been defined as the record of outcomes produced on a specified job function or activity during a specified time period, Steve Brown $(2005: 204)$. Performance is a deceptively simple term. At the most general level, it can be defined simply as "all of the behaviors employees engage in while at work". Job performance represents behaviors employees engage in while at work that contribute to organizational goals, Steve Jex (2008:96). High Job Performance will be achieved if the rules that have been established by an organization can be done well, and effect by:

\subsection{Autonomy}

The authority given to the teacher in preparing the calendar schedule for the subjects, will make it easier for the teacher to plan all of their activities. Teachers who are given authority in determining lesson schedules, determining procedures in work and controlling the time of work will result in improved performance for teachers. Teachers are responsible for planning, learning methods, and even have the courage to risk arising from the decision. The autonomy of labor is the result of the freedom to do what the teacher considers best in certain circumstances. The work remains in a structural space and is still within the limits of supervisory leadership. Teacher's autonomy is also the coverage to which employees can get used to changing the way they work without getting out of organizational rules. Therefore, the autonomy of work is the authority that a person has to take decisions and act and the courage to bear the risk of the work done by the employee in achieving his goal. Autonomy is the authority that a person has to make decisions and act and courage to bear the risk of the work done by employees in achieving their goals, with indicators: determining work schedules, determining procedures at work, controlling time at work.

The freedom and independence to make decisions and have personal control over one's work on a day to day basis, Jennifer and Jones (2012:147). The extend to which the job enables an individual to experience freedom, independence, and discretion in both scheduling and determining the prosedures used in completing the job, Kreitner and Kinicki (2010:233). The degree to which the job provides freedom, independence, and discretion to the individual performing the work. Autonomy comes in multiple forms, including the freedom to control the timing, scheduling, and sequencing of work activities, as well as the prosedures and methods used to complete work task, Colquitt, LePine, Wesson (2011:115). Autonomy is the degree to which a job gives employees the freedom, independence, and discretion to schedule their work and determine the prosedures used in completing it. In autonomous jobs, employees make their own decisions rather that relying on detailed instructions from supervisors or procedure manuals, McShane and Von Glinow (2008:179). Autonomy is the degree to which the worker has freedom. Discretion, and self determination in planning and carrying out tasks, Richard (2012:484). The extent to which the job provides empowerment and discretion to an employee in scheduling task and in determining procedures to be used in carrying out those tasks, Slocum and Hellriegel (2007:403). A feeling of autonomy could result from the freedom to do what the employee considers best in a particular situation. In jobs that are highly structured and controlled by management, it is difficult to create tasks that lead to a feeling autonomy, Ivancevich, Konopaske, Matteson (2008:180). Autonomy is the extent of individual freedom and discretion in the work and its scheduling. More autonomy leads to a greater feeling of personal responsibility for the work, Robert Mathis et al (2014:122). The degree to which the job gives the worker freedom, discretion, and independence in scheduling the work and determining how to do the work, Phillips (2012:217).

\subsection{Personality}

Teachers, who are willing to interact with other teachers, will get a lot of positive feedback in carrying out their work. The inconvenience of teachers in socializing with other colleagues, makes teacher will feel comfortable in working. Teachers who are adaptable to their work environment will be happy to do their work. Thus, personality is a picture of the behavior within the teacher that tends to be felt by him that develops, manifests and underlies patterns of thinking, awareness, seeing things, feeling and acting on life situations. Personality is a 
picture of a person's behavior that develops, manifests and underlies patterns of thinking, awareness, seeing things, feeling and acting on life situations, with indicators: interactions with others, individual openness, behavior patterns at work, adapting to work and socializing with other people.

The pattern of relatively enduring ways that a person feels, thinks, and behaves. Personality is an important factor in accounting for why employees act the way they do in organizations and why they have favorable or unfavorable attitudes toward their jobs and organizations, Jennifer and Jones (2012:38). Personality is the overall combination of characteristics that capture the unique nature of a person as that person reacts to and interacts with others, Schermerhorn (2010:31). Personality is defined as the combination of stable physical and mental characteristics that give the individual his or her identity. These characteristics or traits including how one looks, thinks, acts, and feels are the product of interacting genetic and enviromental influences, Kreitner and Kinicki (2010:133). The relatively stable pattern of behaviors and consistent internal states that explain a person's behavioral tendencies. Personality has both internal and external elements. External traits are the observable behaviors that we rely on to identify someone's personality. The internal states represent the thoughts, values, and genetic characteristics that we infer from the observable behaviors, McShane and Von Glinow (2008:51). Personality refers to a relatively stable set of characteristics, temperament, and tendencies that shape the similarities and differences in people's behavior. The number of aspects of personality that could serve as stress moderators is quite large. The big five model of personality is made up of five dimensions: extroversion, emotion stability, agreeableness, conscient iousness, and openness to experience, Gibson et al (2006:212). Represents the overall profile or combination of stable psycological attributes that capture the unique nature of a person. Therefore, personality combines a set physical and mental characteristics that reflect how a person look, thinks, acts and feels, Slocum and Hellriegel (2007:312). Personality is the set of characteristics that underlie a relatively stable pattern of behavior in response to ideas, objects, or people in the environment. Managers who aprreciate the ways their employees personalities differ have insight into what kinds of leadership behavior will be most influential, Richard (2012:413). Personality refers to the structures and propensities inside people that explain their characteristic patterns of thought, emotion, and behavior. Fortunately, it turns out that most adjectives are variations of five broad dimensions or "factor" that can be used to summarize our personalities. Those five personality dimensions include conscientiousness, agreebleness, neuroticism, openness to experience, and extraversion, Colquitt LePine, Wesson (2011:294). Personality is defined as a relatively stable set of characteristics, tendencies, and temperaments that have been significantly formed by inheritance and by social, cultural, and environmental factors. This set of varibles determines the commonalities and differences in the behavior of individuals (thoughts, feelings, and actions) that have continuity over time and that may not be easyly understood as the sole result of the social and biological pressures of the moment, Shani et al (2009:80). The relatively stable set of psychological attributes that distinguish one person from another. A long standing debate among psychologists often expressed as nature versus nurture is the extent to which personality attributes are inherited from our parents or shaped by our environment, Griffin $(2007 ; 63)$.

\subsection{Stress}

Every person will have the opportunity to face a problem in him. Both these problems are positive or negative. So hopefully everyone must be able to solve a problem that occurs. Solving problems also requires time, energy, thought and a lot of consideration. The situation of someone who is unable to solve a problem in his life will be faced with discomfort. This discomfort makes the pressure in him which leads to stress. Stress is a phenomenon that often occurs in employees when the employee is doing work activities. Stress is the emotional and psychological response of a depressed condition that is felt and arises when the demands of the work exceed the workload in resolving a particular problem or job and their interactions with others that make a person uncomfortable working with indicators: changes in work situation, excessive reaction to consequences work, psychological response to work demands, psychological conditions, physical tension due to anxiety.

Stress is the experience of opportunities or threats that people perceive as important and also perceive they might not be able to handle or deal with effectively. Several significant aspects of stress are highlighted in this definition. First, stress can be experienced because of both opportunities and threats. An opportunity is something that has the potential to benefit a person. A threat is something that has the potential to harm a person, Jennifer and Jones (2012:245). An adaptive response, mediated by individual characteristics and or psychological processes, that is a consequence of any external action, situation, or event that places special physical and or psychological demands upon a person. This defenition is not as difficult as it seems when we reduce it to three inter-related dimensions of stress: (1) environmental demands, referred to as stressors, that produce (2) an adaptive response that is influenced by; (3) individual differences, Kreitner and Kinicki (2008:551). Stress is defined as a psychological response to demands that possess certain stakes and that tax or exceed a person's capacity or resources. This defenition of stress ilustrates that it depends on both the nature of the demand and the person who confronts it. People differ in terms of how they evaluate stressors and the way they cope with them. AS a result, different people may experience different levels of stress even when 
confronted with the exact same situation, Colquitt et al (2011:144). Stress is a dynamic condition in which an individual is confronted with an opportunity, demand, or resource related to what the individual desires and for which the outcomes is perceived to be both uncertain and important, Robbins (2011:641). Stress is the excitement, feeling of anxiety, and/or physical tension that occurs when the demands placed on an individual are thought to exceed the person's ability to cope. This most common view of stress is often called distress or negative stress. Stressors are the psychological demands in the environtment that cause this condition. They can take various forms, but all stressors have one thing in common: They create stress or the potential for stress when an individual perceives them as representing a demand that exceeds that person's ability to respond, Slocum and Hellriegel (2007:448). Stress is an adaptive response to a situation that is perceived as challenging or threatening to a person's well-being. The stress response is a complex emotion that produces physiological changes to prepare us for "fight or flight" to defend ourselves from the threat or flee from it, McShane and Von Glinow (2008:198). Stress is an individual's physiological and emotional response to external stimuli that place physical or psychological demands on the individual and create uncertainty and lack of personal control when important outcomes areat stake. These stimuli, called stressors, produce some combination of frustration (the inability to achive a goal, such as the inability to meet a deadline because of inadequate resources) and anxiety (such as the fear of being disciplined for not meeting deadlines), Richard (2012:426). An adaptive response, moderated by individual differences that is a consequence of any action, situation, or event that places special demands on a person, Ivancevich, Konopaske, Matteson (2008:224).

\subsection{Job Satisfaction}

Job satisfaction owned by teachers will improve teacher's performance. Feelings of fun and unpleasant will lead the teacher to take what steps will be done. A teacher can evaluate the results of his work. From the evaluation teachers can conclude the results of his work. Experience in work also helps teachers to find solutions to problems that occur. Thus, the experience of teachers in making mistakes in work will be the teacher's hand to make improvements in the future. Teachers working with adequate facilities will help teachers to do the work. So that all expected school goals in teachers will transpire. Thus, job satisfaction is a person's emotional response conditions that are fun or unpleasant on the results of an individual's assessment of the work in the form of positive feelings towards work and work experience. Job satisfaction is a condition of someone's emotional response that is pleasant or unpleasant to the results of an individual's assessment of the work in the form of positive feelings about work and work experience, with indicators being the results of an assessment of work, problem solving that can be done, intertwined interactions with coworkers, experience in working, work results with the expectations of the organization and the work facilities they have.

The collection of feelings and beliefs that people have about their current jobs. People's levels or degrees of job satisfaction can range from extreme satisfaction to extreme dissatisfaction, Jennifer and Jones (2012:71). Job satisfaction is a pleasurable emotional state resulting from the appraisal of one's job or job experiences. In other word, it represents how you feel about your job and what you think about your job. Employees with high job satisfaction experience positive feelings when they think about their duties or take part in task activities. Employees with low job satisfaction experience negative feelings when they think about their duties or take part in their task activities, Colquitt et al (2011:105). A person's evaluation of his or her job and work context, is probably the most studied attitude in organizational behavior. It is an appraisal of the perceived job characteristics, work environment, and emotional experiences at work. Satisfied employees have a favorable evaluation of their jobs, based on their observations and emotional experience. Job satisfaction is really a collection of attitudes about different aspects of the job and work context, McShane and Von Glinow (2008:115). An affective or emotional response toward various facets of one's job. This definition implies job satisfaction is not a unitary concept. Rather, a person can be relatively satisfied with one aspect of his or her job and dissatisfied with one or more other aspects, Kreitner and Kinicki (2010:170). The extent to which people find fulfillment in their work. Low job satisfaction can result in costly turnover, absenteeism, tardiness, and even poor mental health, Slocum and Hellriegel (2007:325). Describes a positive feeling about a job, resulting from an evaluation of its characteristics. A person with a high level of job satisfaction holds positive feelings about his or her job, while a dissatisfied person holds negative feelings. When people speak of employee attitudes, they usually mean job satisfaction, Robbins (2009:113). An attitude people have about their jobs. It result from their perception of their jobs and the degree to which there is a good fit between them as individuals and the organization, Ivancevich et al (2008;70). Job satisfaction is a positive emotional state resulting from evaluating one's job experiences. One way employers address job satisfaction, and ultimately retention, is by regulary surveing, employees. One specific type of survey used by many organization is an attitude survey, which focuses on employees' feelings and beliefs about their jobs and the organization. Management can respond to the results after they are compiled. If the employer takes responsive actions, employees may view the employer more positively; however, if management ignores the survey result, their inaction can lead to lower job satisfaction, Robert L. Mathis et al (2014:155). An attitude that refelects the extent to which an individual is gratified by or 
fulfilled in his or her work. Extensive research conducted on job satisfaction has indicated that personal factors such as an individual's needs and aspirations determine this attitude along with group and organizational factors such as relationships with co-workers and supervisors and working conditions, work polocies, and compensation. A satisfied employee also tends to be absent less often, to make positive contributions. And to stay with the organization. In contrast, a dissatisfied employee maybe absent more often, may experience stress that disrupts co-workers, ang may be continually looking for another job, Griffin (2007:419).

\section{Methodology}

This quantitative research uses survey method through analysis approach. Before being used in research, an instrument test was conducted to test the validation and reliability of each item so that it could be used in research. The study was conducted on 191 teachers in Bekasi. From the number of teachers as many as 364 teachers were taken using the Slovin formula. A sample of 191 teachers were obtained by a simple random method from the population and spread to senior high school in Bekasi.

The data in this study were concluded using a questionnaire-shaped instrument that included the Job performance questionnaire, autonomy, personality, stress and job satisfaction, which had gone through the stages of empirical validation through instrument trials. Furthermore, the reliability calculation is done on the valid instrument items that indicate the appropriateness of the instrument to be used in research. The results of the validation test and instrument reliability calculation are as follows: (1) job performance questionnaire, validation $=94.29 \%$, reliability $=0.954$, (2) autonomy questionnaire, validation $=88.57 \%$, reliability $=0.952,(3)$ personality questionnaire, validation $=88.57 \%$, reliability $=0.967,(4)$ stress questionnaire, validation $=91.43 \%$, reliability $=0.958$, (5) job satisfaction questionnaire, validation $=91.43 \%$, reliability $=0.964$. So it was concluded that all valid instrument items are reliable instruments.

Research data analysis techniques were analyzed using descriptive analysis and inferential analysis with a path analysis approach. Descriptive analysis is done by calculating the average value, median, mode, variance, and standard deviation. The data characters of each variable are displayed in the frequency distribution and histogram tables. Inferential analysis is preceded by analysis requirements test, consisting of estimated error normality test, significance test, and linearity test.

\section{Result and Discussion}

Data analysis to test the research hypothesis is carried out by statistical analysis or path analysis. Before testing the hypothesis first, the analysis of the requirements analysis is carried out which includes the following: (1) testing the estimated normality error, and (2) the significance test and regression linearity.

Test the estimated normality error using the liliefors test. The test criteria is if $\mathrm{L}_{\text {counts }}<\mathrm{L}_{\text {table }}$ at $\alpha=0.05$, then the regression equation is normally distributed. Based on the calculation of the $\mathrm{Y}$ error estimation normality test for $\mathrm{X}_{1}, \mathrm{Y}$ for $\mathrm{X}_{2}, \mathrm{Y}$ for $\mathrm{X}_{4}, \mathrm{X}_{4}$ for $\mathrm{X}_{1}, \mathrm{X}_{4}$ for $\mathrm{X}_{2}, \mathrm{X}_{4}$ for $\mathrm{X}_{3}$ all of them indicate that $\mathrm{L}_{\text {counts }}<\mathrm{L}_{\text {table }}$ so that all regression equations are normally distributed.

For the significance test carried out by ANAVA calculation with the test criteria is if $F_{\text {count }}>F_{\text {table }}$ at $\alpha=0.01$ then the regression coefficient between variables is significant. Based on the results of the calculation of the significance test $\mathrm{Y}$ for $\mathrm{X}_{1}, \mathrm{Y}$ for $\mathrm{X}_{2}, \mathrm{Y}$ for $\mathrm{X}_{4}, \mathrm{X}_{4}$ for $\mathrm{X}_{1}, \mathrm{X}_{4}$ for $\mathrm{X}_{2}, \mathrm{X}_{4}$ for $\mathrm{X}_{3}$, all of them indicate that $\mathrm{F}_{\text {count }}>$

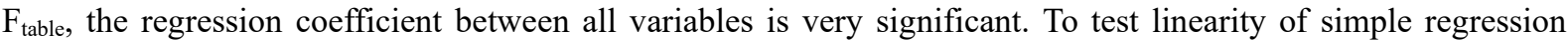
equations with criteria that if $\mathrm{F}_{\text {count }}<\mathrm{F}_{\text {table }}$ then the relationship between variables is linear. Based on the calculation of the $\mathrm{Y}$ linearity test for $\mathrm{X}_{1}, \mathrm{Y}$ for $\mathrm{X}_{2}, \mathrm{Y}$ for $\mathrm{X}_{4}, \mathrm{X}_{4}$ for $\mathrm{X}_{1}, \mathrm{X}_{4}$ for $\mathrm{X}_{2}, \mathrm{X}_{4}$ for $\mathrm{X}_{3}$, all of them show that $\mathrm{F}_{\text {counts }}<\mathrm{F}_{\text {table }}$, so all relationships between variables are linear.

After testing the estimated normality error, significance test and regression linearity, path analysis is conducted to test the research hypothesis. The following table describes the results of the calculation and path coefficient testing with $t_{\text {table }}=2.334$ for $\alpha=0.01$ and $t_{\text {table }}=1.653$ for $\alpha=0.05$ with the criteria if $t_{\text {count }}>$ from $t_{\text {table }}$ then the path coefficient test results show that the path is very good and can explain the influence between variables.

Table 1. Results and Path Coefficient Testing

\begin{tabular}{cccc}
\hline Path & Correlation Coefficient & Path Coefficient & $\mathrm{t}_{\text {count }}$ \\
\hline $\mathrm{X}_{1}$ On $\mathrm{Y}$ & $\mathrm{r}_{1 \mathrm{y}}=0,518$ & $\mathrm{p}_{\mathrm{y} 1}=0,341$ & 5,775 \\
\hline $\mathrm{X}_{2}$ On Y & $\mathrm{r}_{2 \mathrm{y}}=0,565$ & $\mathrm{p}_{\mathrm{y} 2}=0,349$ & 4,886 \\
\hline $\mathrm{X}_{4}$ On Y & $\mathrm{r}_{4 \mathrm{y}}=0,495$ & $\mathrm{p}_{\mathrm{y} 4}=0,150$ & 2,092 \\
\hline $\mathrm{X}_{1}$ On $\mathrm{X}_{4}$ & $\mathrm{r}_{14}=0,359$ & $\mathrm{p}_{41}=0,147$ & 2,259 \\
\hline $\mathrm{X}_{2}$ On $\mathrm{X}_{4}$ & $\mathrm{r}_{14}=0,637$ & $\mathrm{p}_{42}=0,582$ & 9,825 \\
\hline $\mathrm{X}_{3}$ On $\mathrm{X}_{4}$ & $\mathrm{r}_{34}=-0,185$ & $\mathrm{p}_{43}=-0,016$ & $-0,263$ \\
\hline
\end{tabular}

Thus it can be concluded the path between autonomy variables on job performance, personality on job performance, job satisfaction on job performance, autonomy on job satisfaction, personality on job satisfaction, and stress on job satisfaction the path coefficient is significant because the $t_{\text {count }}>t_{\text {table. }}$. The path coefficient test 
results in this study indicate that the path is very well shaped and can explain the influence of autonomy, personality, stress and job satisfaction on Job performance of teachers in Bekasi. So that it can explain the influence of exogenous variables with endogenous variables analyzed. The results of the study mean that generally teachers in Bekasi there are five positive direct influences: (1) autonomy on job performance, (2) personality on job performance, (3) job satisfaction on job performance, (4) autonomy towards on job satisfaction, (5) personality towards on job satisfaction, and one negative direct influence; (1) stress towards on job satisfaction. In detail the discussion of the results of the analysis and testing of the research hypothesis is described as follows:

\section{a. Effect of Autonomy on Job Performance}

To prove work autonomy has a direct positive effect on performance, the statistical hypothesis is: $\mathrm{H}_{0}: \beta_{\mathrm{y} 1} \leq 0, \mathrm{H}_{1}$ : $\beta_{\mathrm{y} 1}>0$. The result of calculation of the effect of autonomy on performance, obtained path coefficient of 0.341 and tcount value of the coefficient of this path of $5.775, \mathrm{t}(5,775)>\mathrm{t}_{\text {table }}(2.346)$ at $\alpha=0.01$, then $\mathrm{H}_{0}$ is rejected. It can be concluded that there is a positive direct effect of work autonomy on performance. That is, increased work autonomy will lead to improved performance.This is in accordance with the theory proposed by Daft (2012), which states that "five dimensions that determine a job's motivational potential: variety skills, task identity, task significance, autonomy, feedback. Daft said that giving autonomy for teachers in schools resulted in a high level of autonomy for high school teachers, improvement of teacher's performance. The result of research indicates that autonomy has an effect onto performance. Namely, it can be interpreted that autonomy owned by teacher, causingsche an increase of teacher's performance of Senior High School te in Bekasi District. The teacher's authority in setting schedule, procedure of learning method and time control will improve teacher's performance. Based on this empirical evidence, it is said that these findings indicate that autonomy is one of the variables that directly affect the performance variables. The autonomy will affect teacher's performance improvement. A research conducted by Raza (2013) states that, "job autonomy improves performance because when employees are provided a support to exercise job autonomy then they will consider that they are trusted to perform the task". This provides an amplifier for the results of this hypothesis test that autonomy has a direct positive effect on performance.

\section{b. Effect of Personality on Job Performance}

To prove personality has a direct positive effect on performance, the statistical hypothesis is: $\mathrm{H}_{0}$ : $\beta_{\mathrm{y} 2} \leq 0, \mathrm{H}_{1}$ : $\beta_{\mathrm{y} 2}>0$. The result of calculation of personality influence on performance, obtained path coefficient of 0.349 and $t_{\text {count }}$ of coefficient of this line $4,886, t_{\text {count }}(4,886)>t_{\text {table }}(2.346)$ at $\alpha=0.01$, then $H_{0}$ is rejected. Thus, it is concluded that there is a direct positive influence of personality on performance. The results of this study of the direct positive effects of personality on the performance of teachers examined in accordance with the theory proposed by Colquitt (2009), which states that, "of the big five, conscientiousness has the strongest efffect on task performance, partly because conscientiousness employees have higher levels of motivation than other employees ". The results show that the personality effect on the performance can be interpreted that a good personality, will lead to increased performance of high school teachers in the Bekasi District. Based on this empirical evidence, it is said that these findings indicate personality is one of the variables that directly affect the performance variables. Good personality will affect teacher's performance improvement. According to Davis Mkoji (2012), in his journal entitled The Influence of Personality Dimensions on Organization Performance, states that personality affects their performance. This provides an amplifier for the results of this hypothesis test that the personality has a positive direct effect on performance

\section{c. Effect of Job satisfaction on Job Performance}

To prove job satisfaction has a direct positive effect on performance, the statistical hypothesis is: $\mathrm{H}_{0}: \beta_{\mathrm{y} 4} \leq 0, \mathrm{H}_{1}$ : $\beta_{\mathrm{y} 4}>0$. The result of calculation of the effect of job satisfaction on performance, obtained path coefficient of 0.150 and $t_{\text {count }}$ value of this path coefficient of 2.092, $\mathrm{t}_{\text {count }}(2.092)>\mathrm{t}_{\text {table }}(1.653)$ at $\alpha=0.05$, then $\mathrm{H}_{0}$ is rejected. Thus, it is concluded that there is a direct positive effect of job satisfaction on performance. The results of this study on the direct positive effects of job satisfaction on the performance of teachers studied in accordance with the theory proposed by Colquitt (2011), which states that, "Job satisfaction has a moderate positive effect on job performance. People who get job satisfaction at a school will feel comfortable in the school. With the confidence that grows due to job satisfaction, the teacher will be able to show a determination that he will do other things more useful for himself and the school where he teaches. The results showed that job satisfaction affects the performance, can be interpreted that the job satisfaction felt by teachers, will lead to increased the performance of high school teachers in Bekasi District. Job satisfaction of teachers in carrying out their duties at school will generate enthusiasm in carrying out daily tasks in school and increasing the emotional bond between teachers and schools. A strong emotional bond of the teacher toward the school will be realized with his involvement with all activities at school maximally and done with pleasure and sincerity. Based on this empirical evidence, it is said that these findings indicate job satisfaction is one of the variables that directly affect the performance variable. High job satisfaction will affect on the increasing of the teacher's performance.

According to Latif (2003) in his journal entitled Impact of Employee's Job Satisfaction on Organizational 
Performance, states that "employee satisfaction plays a considerable role in enhancing the firm's profitability and improving operational performance of the organization and quality of good and services. There is no doubt in it that employee satisfaction is critical to attain quality and profitability in organization. This provides an amplifier for the test results of this hypothesis that job satisfaction has a direct positive effect on performance.

\section{d. Effect of Autonomy on Job Satisfaction}

To prove work autonomy has a direct positive effect on job satisfaction, the statistical hypothesis is: $\mathrm{H}_{0}$ : $\beta_{41} \leq 0$, $\mathrm{H}_{1}: \beta_{41}>0$. Result of calculation of influence of work autonomy to job satisfaction, obtained path coefficient equal to 0,147 and $t_{\text {count }}$ of coefficient of this path equal to 2,259 , $t_{\text {count }}(2,259)>t_{\text {table }}(1.653)$ at $\alpha=0.05$, then $\mathrm{H}_{0}$ is rejected. Thus it is concluded that there is a positive direct effect of autonomy on job satisfaction. The results of this study of the positive direct effect of autonomy on teacher work satisfaction is studied in accordance with the theory proposed by Phillips (2012) which states that "Satisfaction with the nature of the work it self is the largest influence on job satisfaction. If you do not like the work you are doing, it is hard to be satisfied with your job. Challenging work, autonomy, variety, and job scope also increase job satisfaction. "Working autonomy of teachers will have an impact on the teacher's performance. With the authority to determine the timetable of the lesson, time control, and setting learning methods will motivate teachers to always do a good job. The result of the research shows that work autonomy has an effect on job satisfaction, it can be interpreted that high work autonomy which owned by teacher, will cause the performance improvement of Senior High School teacher in Bekasi District. Based on this empirical evidence, it is said that these findings indicate autonomy is one of the variables that directly affect the variable job satisfaction. According to Anum in a journal entitled Impact of Job Autonomy and Supervisor's and Co-Workers' Support on Jon Burnout and Satisfaction (2013), he states that there is an influence of autonomy on job satisfaction. He explainins that high work autonomy leads to improved performance. This provides an amplifier for the test results of this hypothesis that work autonomy directly implies positive effect on job satisfaction.

\section{e. Effect of Personality on Job Satisfaction}

To prove the personality has a direct positive effect on job satisfaction, the statistical hypothesis is: $\mathrm{H}_{0}$ : $\beta_{42} \leq 0$, H1: $\beta_{42}>0$. The result of calculation of the influence of personality to job satisfaction, obtained path coefficient of 0.582 and $t_{\text {count }}$ of coefficient of this path equal to $9,825, t_{\text {count }}(9,825)>t_{\text {table }}(2.364)$ at $\alpha=0.01$, then $H_{0}$ is rejected. Thus it is concluded that there is a direct positive influence of personality on job satisfaction. The results of the research on the direct positive effects of personality on teacher work satisfaction are studied in accordance with the theory proposed by Colquitt (2011),which states that Research now acknowledges that employees genes have a significant impact on their job satisfaction and that much of that genetic infleunce in due to extraversion". The results showed that personality affects the job satisfaction, it can be interpreted that a good personality, will lead to increased job satisfaction of teachers of State Senior High Schools in Bekasi. Based on this empirical evidence, it is said that these findings indicate personalty as one of the variables that directly affect the variable job satisfaction. Personality will affect the increasing of job satisfaction in teacher. According to Mullins (2010) in his book, Management \& Organizational Behavior, he states that, "the level of job satisfaction is affected by a wide range of variables relating to individuals, social, culture, organizational and environmental factors. Individual factors include personality, education and qualifications, intellegence, and abilities, age, marital status, orientation to work". This provides an amplifier for the results of this hypothesis test that the personality has a positive direct effect on job satisfaction.

\section{f. Effect of Stress on Job Satisfaction}

To prove the personality has a direct positive effect on job satisfaction, the statistical hypothesis is: $\mathrm{H}_{0}$ : $\beta_{43} \geq 0$, $\mathrm{H}_{1}: \beta_{43}<0$. The result of calculation of stress influence on job satisfaction, obtained coefficient of path equal to 0.016 and $t_{\text {count }}$ of coefficient of this path equal to $-0.263, \mathrm{t}_{\text {count }}(-0.263)<\mathrm{t}_{\text {tabel }}(2.364)$ at $\alpha=0.01$, then $\mathrm{H}_{0}$ is rejected. Thus, it is concluded that there is a direct negative effect of stress on job satisfaction. The results of research on the direct positive effects of stress on job satisfaction of teachers is in accordance with the research theory proposed by Jennifer (2012). She stated that the negative psychological consequence of stress is that people tend to have more negative attitudes when they experience stress. Highly stressed employees tend to have a more negative outlook on how much the job satisfaction and organizational commitment ". The results showed that stress affects the job satisfaction, it can be interpreted that low stress, will lead to increased job satisfaction of teachers of senior high school in Bekasi District. Based on this empirical evidence, it is said that these findings indicate stress is one of the variables that directly affects the variable job satisfaction. Low stress will affect the increase of job satisfaction in teachers. According to Sheraz (2014), in his research entitled, Antecedents of Job Stress and its Impact on Employee's Job Satisfaction and Turnover Intentions, affirmed that low stress affects increased job satisfaction. This provides an amplifier for the results of this hypothesis test that stress has a direct negative effect on job satisfaction. 
Table 2. Recapitulation of the Result of Hypothesis Test

\begin{tabular}{|c|c|c|c|c|c|c|}
\hline No & Hypothesis & Statistic Test & Decision & & Conclusion & \\
\hline 1 & $\begin{array}{lccc}\begin{array}{l}\text { Autonomy directly } \\
\text { performance positively }\end{array} & \text { influence } & \text { job } \\
\end{array}$ & $\begin{array}{l}\mathrm{H}_{0}: \beta_{\mathrm{y} 1} \leq 0 \\
\mathrm{H}_{1}: \beta_{\mathrm{y} 1}>0\end{array}$ & $\begin{array}{l}\mathrm{H}_{0} \\
\text { rejected }\end{array}$ & was & $\begin{array}{l}\text { Direct } \\
\text { influence }\end{array}$ & positive \\
\hline 2 & $\begin{array}{l}\text { Personality directly } \\
\text { performance positively }\end{array}$ & $\begin{array}{l}\mathrm{H}_{0}: \beta_{\mathrm{y} 2} \leq 0 \\
\mathrm{H}_{1}: \beta_{\mathrm{y} 2}>0\end{array}$ & $\begin{array}{l}\mathrm{H}_{0} \\
\text { rejected }\end{array}$ & was & $\begin{array}{l}\text { Direct } \\
\text { influence }\end{array}$ & positive \\
\hline 3 & $\begin{array}{l}\text { Job satisfaction directly influences job } \\
\text { performance positively }\end{array}$ & $\begin{array}{l}\mathrm{H}_{0}: \beta_{\mathrm{y} 4} \leq 0 \\
\mathrm{H}_{1}: \beta_{\mathrm{y} 4}>0\end{array}$ & $\begin{array}{l}\mathrm{H}_{0} \\
\text { rejected }\end{array}$ & was & $\begin{array}{l}\text { Direct } \\
\text { influence }\end{array}$ & positive \\
\hline 4 & $\begin{array}{l}\text { Autonomy directly } \\
\text { satisfaction positively }\end{array}$ & $\begin{array}{l}\mathrm{H}_{0}: \beta_{41} \leq 0 \\
\mathrm{H}_{1}: \beta_{41}>0\end{array}$ & $\begin{array}{l}\mathrm{H}_{0} \\
\text { rejected }\end{array}$ & was & $\begin{array}{l}\text { Direct } \\
\text { influence }\end{array}$ & itive \\
\hline 5 & $\begin{array}{l}\text { Personality directly } \\
\text { satisfaction positively }\end{array}$ & $\begin{array}{l}\mathrm{H}_{0}: \beta_{42} \leq 0 \\
\mathrm{H}_{1}: \beta_{42}>0\end{array}$ & $\begin{array}{l}\mathrm{H}_{0} \\
\text { rejected }\end{array}$ & was & $\begin{array}{l}\text { Direct } \\
\text { influence }\end{array}$ & positive \\
\hline 6 & $\begin{array}{l}\text { Personality directly } \\
\text { satisfaction positively }\end{array}$ & $\begin{array}{l}\mathrm{H}_{0}: \beta_{43} \geq 0 \\
\mathrm{H}_{1}: \beta_{43}<0\end{array}$ & $\begin{array}{l}\mathrm{H}_{0} \\
\text { rejected }\end{array}$ & was & $\begin{array}{l}\text { Direct } \\
\text { influence }\end{array}$ & tive \\
\hline
\end{tabular}

\section{Conclusion}

Based on the results of hypothesis testing and discussion of the results of research that has been stated in the previous chapter, through research conducted on high school teachers in the region of Bekasi District obtained the following research conclusions: (1) autonomy implies positive effect directly on the job performance of teachers senior high school in Bekasi District. This means that increased autonomy of work will lead to high performance improvement; (2) personality has a direct positive effect on the job performance of high school teachers in Bekasi District. This means that an accurate personality enhancement will lead to high performance improvements; (3) job satisfaction has a direct positive effect on the job performance of high school teachers in Bekasi District. This means that increased high job satisfaction will lead to high performance improvement; (4) autonomy has a direct positive effect on the job satisfaction of teachers of Senior high school in Bekasi District. This means that high work autonomy will cause a high increase in job satisfaction; (5) personality has a direct positive effect on the job satisfaction of senior high school teacher in Bekasi District. This means that a good personality enhancement will lead to a high increase in job satisfaction; (6) Stress has a direct negative effect on the job satisfaction of senior high school teacher in Bekasi District. This means that low stress will lead to increased job satisfaction. Based on the above research findings, it can be stated that performance can be influenced by work autonomy, personality, stress, and job satisfaction variables. However, other variables still need to be a concern in the follow up studies related to performance variables. Based on the conclusions of this study shows that in improving the performance of teachers can be done by improving autonomy, personality, stress, and job satisfaction in the teacher self.

\section{Acknowledgement}

By saying praise and gratitude to the presence of God Almighty, because of all His mercy and grace, the author can complete the writing of this research. As one of the requirements This research entitled "The Effect of Autonomy, Personality, Stress and Job Satisfaction to Job Performance of Teachers at Senior High School In Bekasi is submitted as the final requirement to obtain the title of Doctor of Education Management from the Postgraduate Program of the Jakarta State University. In arranging this research, a lot of people have provided motivation, advice, and support for the researcher. In this valuable chance, the researcher intended to express his gratitude and appreciation to all of them. First, the researcher's deepest appreciation goes to all my falily for the endless love, pray, and support and for the phone call every week in order to remind me to keep going and never giving up.

\section{References}

Colquitt, LePine, Wesson, (2009). Organizational Behavior, Improving Performance and Commitment in the Workplace, Second Edition, New York : McGraw-Hill

Colquitt, LePine, Wesson, (2011). Organizational Behavior, Improving Performance and Commitment in the Workplace, Second Edition, New York : McGraw-Hill

Davis Mkoji, Damary Sikalieh, (2012). The Influence of Personality Dimensions on Organization Performance, International Journal of Humanities and Social Science, Vol. 2, N0. 17

Gibson, Ivancevich, Donnelly, Konopaske,(2006). Organizations, Behavior Structure Processes, New York, McGraw-Hill

Griffin Moorhead, (2007). Organizational Behavior, Managing People and Organizations, New York: Houghton Mifflin Company

Iqbal, Anum, (2013). Impact of Job Autonomy and Supervisor's and Co workers Support on Job Burnout and Satisfaction: The Mediating Role of Emotional Labor, International Journal of Economics and Management 
Sciences Vol. 2, No. 6

Ivancevich, Konopaske, Matteson, (2008). Organizational Behavior and Management, Eighth Edition, New York: McGraw-Hill Irwin

Jennifer M.george, Gareth Jones, (2012). Understanding and Managing Organizational Behavior, Sixth Edition ,New Jersey : Pearson

John W. Slocum,Jr, Don Hellriegel, (2007). Fundamentals of Organizational Behavior, USA: Thomson Shout Western

Kreitner, Kinicki, (2008). Organizational Behavior, New York: McGraw-Hill

Muhammad Shahzad Latif, et all, (2013). Impact of Employee's Job Satisfaction on Organizational Performance, European Journal of Business and Management, Vol. 5, No. 5

Laurie J. Mullins, (2010). Management \& Organizational Behavior, London: Pearson

McShane, Von Glinow, (2008). Organizational Behavior, Fourth Edition, New York, Mc Graw-Hill

Michael Armstrong, (2006). Performance Management, Third Edition, London : Kogan Page

Naviq, Raza, Maria Ishtiaq, Nousheen Kanwal, Mohsin Ali, (2013). Impact of Jon Autonomy on Organizational Commitment and Job Satisfaction : The Moderating Role of Organizational Culture in Fast Food Sector of Pakistan, International Journal of Business and Management, Vol. 8, No. 17

Phillips, Gully, (2012). Organizational Behavior, Toos for Success, United State of America, South-Western Cengage Learning

Richard L. Daft, (2012). New Era Of Management, 10th Edition, China, South-Western Cengage Learning

Robert L. Mathis, Jhon H.Jackson, Sean R. Valentine, (2014). Human Resource Management, Fourteenth Edition, Canada: Cengage Learnin

Schermerhorn. Jhon. R, James G.Hunt, Richard Osborn, Mary Uhl Bien, (2010). Organizational Behavior, United States of America: Jhon Wiley \& Sons

Shani,A.B, Dawn Chandler, Jean, F.C, James B. Lau, (2009). Behavior In Organizations, An Experience Approach, Ninth Edition, New York, McGraw-Hill

Sheraz, Ahmad, at all, (2014). Antecedents of Job Stress and its Impact on Employee's Job Satisfaction and Turnover Intentions, International Journal of Learning \& Development, Vol. 4, No. 2

Steven D.Brown, Robert W. Lent, (2005). Career Development and Counseling, Putting Theory and Research to Work, John wiley \& Sons,Inc

Steve,M.Jex, (2008). Thomas W. Britt, Organizational Psychology, A Scientist Practitioner Approach, Second Edition, New Jersey, Jhon Wiley \& Sons, Inc

Stephen P.Robbins, Timothy A.Judge, (2009). Organizational Behavior, New Jersey: Pearson 